\title{
The Detection of Enteroviruses in Sewage Using Caco-2 Cells
}

\author{
MAGDALENA WIECZOREK ${ }^{\star}$, ŁUKASZ KURYK, AGNIESZKA WITEK, ANNA DIUWE \\ and BOGUMIŁA LITWIŃSKA \\ National Institute of Public Health - National Institute of Hygiene \\ Department of Virology, Warsaw, Poland
}

Received 29 June 2012, revised 20 September 2012, accepted 24 September 2012

Abstract

The work presented here demonstrates the utility of Caco- 2 cells to detect enteroviruses in sewage. Viruses were concentrated by beef extract elution and organic flocculation prior to analysis by cell culture assays and RT-PCR. Enteroviruses were detected in all sewage samples, but only one sample was positive solely in RT-PCR assay. We proved that Caco-2 cells were more effective than RD and L20B cells in enterovirus isolation, depending on procedures used in the inoculation process.

Key words: Caco-2 cells, enteroviruses, sewage

Sewage is a rich source of enteric viruses circulating in the community. The level of culturable viruses in raw sewage may reach above 10,000 infectious units per litre. The amount of enteric viruses is relatively stable in sewage, with a peak in the autumn/winter months. Sewage investigation by molecular and virological methods is applied to obtain information about the circulation of enteric viruses in the community, including viruses causing both symptomatic and asymptomatic infections (Fong and Lipp, 2005).

Enteric viruses may be detected by molecular methods, such as PCR. Although detection by PCR reveals the presence of viral RNA or DNA, it does not indicate the infectivity of the virus. The detected genomic material may be present in otherwise defective virus particles that are not able to bind to or replicate in the host cells. The infectivity of viruses may be determined with the use of cell cultures, such as Caco-2 and RD (Terletskaia-Ladwig et al., 2008; Sedmak et al., 2005). It has been found that Caco-2 cells support growth of many viruses, including enteroviruses, rotaviruses, adenoviruses, and astroviruses (Hamza 2011; Pinto et al., 1995).

Enteroviruses are members of the picornavirus family, a large and diverse group of small RNA viruses characterized by a single positive-strand genomic RNA. They affect millions of people worldwide each year, and are often found in the respiratory secretions and in stool of an infected person. Infection can result in a wide variety of symptoms ranging from mild respiratory illness (common cold), through hand, foot and mouth disease, acute hemorrhagic conjunctivitis, aseptic meningitis, myocarditis, to severe neonatal sepsislike disease and acute flaccid paralysis. No single cell line currently in use supports the growth of all known enterovirus serotypes. Most of them have been propagated in $\mathrm{RD}$ cells, but in practice isolation from clinical and environmental material is often unsuccessful (Lipson et al., 1988; Witek et al., 2011).

The present study was conducted to obtain information about the utility of Caco- 2 cell in the isolation of enteroviruses from sewage. Sewage samples from 14 towns in Poland were examined for the presence of enteroviruses by molecular and cell culture methods.

Samples of raw sewage were collected in 14 Polish towns in December 2011. A total of 14 sewage samples were processed according to the protocol described earlier (Zurbriggen et al., 2008). A volume of $200 \mu \mathrm{l}$ of sewage concentrates were inoculated into tubes with $\mathrm{RD}$ and L20B cells according to $\mathrm{WHO}$ procedures. The tubes were incubated at $37^{\circ} \mathrm{C}$. Each specimen underwent three passages in RD and L20B cells. Samples demonstrating viral cytopathic effect $(\mathrm{CPE})$ were identified by neutralization assay using specific antisera (National Institute of Public Health and the Environment, the Netherlands).

* Corresponding author: M. Wieczorek, Chocimska 24 Str., 00-791 Warsaw, Poland, phone: +48 225421230 , fax: +48 22 54 385, e-mail: mrechnio@pzh.gov.pl 
A volume of $200 \mu \mathrm{l}$ of sewage concentrates were inoculated into tubes with Caco- 2 cells, also. In the first variant, tubes with monolayer of Caco-2 cells in maintenance medium were inoculated with $200 \mu$ of sewage sample; in the second variant, samples were incubated with $10 \mu \mathrm{g} / \mathrm{ml}$ trypsin for $1 \mathrm{~h}$ at $37^{\circ} \mathrm{C}$ and next were added onto tube cultures with maintenance medium; in the third variant, samples were inoculated onto tube cultures of Caco- 2 cells without medium and incubated for $1 \mathrm{~h}$ at $37^{\circ} \mathrm{C}$ and after elimination of inoculum, $2 \mathrm{ml}$ of maintenance medium were added to those tubes; and in the fourth variant, samples were incubated with $10 \mu \mathrm{g} / \mathrm{ml}$ trypsin for $1 \mathrm{~h}$ at $37^{\circ} \mathrm{C}$. Next, after the elimination of the culture medium from the tube, $200 \mu \mathrm{l}$ of those samples were inoculated onto tube cultures of Caco- 2 cells and incubated for $1 \mathrm{~h}$ at $37^{\circ} \mathrm{C}$. Then after elimination of inoculum, $2 \mathrm{ml}$ of maintenance medium with $0.5 \mu \mathrm{g} / \mathrm{ml}$ trypsin were added to those tubes. Cytopathic effects were read daily for 7 days, and 3 passages were performed. All strains isolated in Caco- 2 cells were re-passaged in RD and L20B cells. Supernatant fluids were used for the RT-PCR detection to confirm the presence of the virus. Viral RNA was extracted from $140 \mu$ of cell culture supernatant or concentrated sewage using spin columns (Qiagen) following the manufacturer's instructions. RT-PCR was carried out using Pan-Enterovirus primers for enterovirus detection based on WHO manual (WHO, 2004). This set of primers produces a product of $114 \mathrm{bp}$ and has been designed to detect and amplify a genome segment present at the 5'-UTR of the enterovirus genomes. RT-PCR amplification was performed: one cycle of reverse transcription at $45^{\circ} \mathrm{C}$ for $20 \mathrm{~min}$; one cycle denaturation at $94^{\circ} \mathrm{C}$ for $2 \mathrm{~min} ; 30$ cycles of denaturation at $94^{\circ} \mathrm{C}$ for $30 \mathrm{~s}$; annealing at $55^{\circ} \mathrm{C}$ for $30 \mathrm{~s}$; elongation at $70^{\circ} \mathrm{C}$ for $30 \mathrm{~s}$ followed by one cycle of elongation at $70^{\circ} \mathrm{C}$ for $7 \mathrm{~min}$. Reaction mixtures were then held at $4^{\circ} \mathrm{C}$. Amplification products were analyzed in $2 \%$ agarose gels, GelRed stained and examined under an UV DNA transilluminator.

Out of the 14 sample sites analysed, 9 were positive for enteroviruses using Pan-enterovirus RT-PCR. Only

Table I

Sewage samples analysis for enteroviruses

\begin{tabular}{|c|c|c|c|c|c|c|c|}
\hline \multirow[b]{2}{*}{ Town } & \multicolumn{2}{|c|}{ Isolation in $\mathrm{RD} / \mathrm{L} 20 \mathrm{~B}$} & \multirow{2}{*}{$\begin{array}{c}\text { RT-PCR } \\
\text { Pan-Entero }\end{array}$} & \multicolumn{4}{|c|}{ Isolation in Caco-2 } \\
\hline & $\mathrm{RD}$ & L20B & & $\begin{array}{c}\text { Incubation (-) } \\
\text { Trypsin }(-)\end{array}$ & $\begin{array}{c}\text { Incubation (-) } \\
\text { Trypsin }(+)\end{array}$ & $\begin{array}{c}\text { Incubation }(+) \\
\text { Trypsin }(-)\end{array}$ & $\begin{array}{c}\text { Incubation }(+) \\
\text { Trypsin }(+)\end{array}$ \\
\hline Koszalin & - & $\begin{array}{c}+ \\
\text { PV-3 }\end{array}$ & - & - & - & - & - \\
\hline Bielsko Biała & - & - & + & - & - & $\begin{array}{c}+ \\
\text { ECHO11 }\end{array}$ & - \\
\hline Pilchowice & - & - & + & - & $\begin{array}{c}+ \\
\mathrm{PV}-3\end{array}$ & - & - \\
\hline Opole & - & - & + & $\begin{array}{c}+ \\
\text { ECHO11 }\end{array}$ & $\begin{array}{c}+ \\
\text { ECHO11 }\end{array}$ & $\begin{array}{c}+ \\
\text { ECHO11 }\end{array}$ & $\begin{array}{c}+ \\
\text { ECHO11 }\end{array}$ \\
\hline Warka & - & - & + & - & - & - & - \\
\hline Radom & $\begin{array}{c}+ \\
\mathrm{PV}-3\end{array}$ & $\begin{array}{c}+ \\
\text { PV-3 }\end{array}$ & - & $\begin{array}{c}+ \\
\mathrm{ECHO} 3\end{array}$ & $\begin{array}{c}+ \\
\mathrm{ECHO} 3\end{array}$ & - & - \\
\hline Piotrków Trybunalski & - & - & + & - & - & - & $\begin{array}{c}+ \\
\mathrm{ECHO} 3\end{array}$ \\
\hline Mińsk Mazowiecki & - & - & - & - & $\begin{array}{c}+ \\
\text { ECHO11 }\end{array}$ & $\begin{array}{c}+ \\
\mathrm{ECHO} 3\end{array}$ & $\begin{array}{c}+ \\
\mathrm{ECHO} 3\end{array}$ \\
\hline Białystok & - & - & + & - & $\begin{array}{c}+ \\
\text { ECHO11 }\end{array}$ & $\begin{array}{c}+ \\
\text { ECHO11 }\end{array}$ & $\begin{array}{c}+ \\
\text { ECHO11 }\end{array}$ \\
\hline Jelenia Góra & - & - & - & - & $\begin{array}{c}+ \\
\mathrm{ECHO} 3\end{array}$ & $\begin{array}{c}+ \\
\mathrm{ECHO} 3\end{array}$ & - \\
\hline Warszawa Południe & - & - & + & - & $\begin{array}{c}+ \\
\mathrm{ECHO} 3\end{array}$ & $\begin{array}{c}+ \\
\mathrm{ECHO} 3\end{array}$ & $\begin{array}{c}+ \\
\text { ECHO11 }\end{array}$ \\
\hline Gdynia & - & $\begin{array}{c}+ \\
\text { PV-3 }\end{array}$ & + & $\begin{array}{c}+ \\
\operatorname{CoxB}\end{array}$ & $\begin{array}{c}+ \\
\text { ECHO3 }\end{array}$ & $\begin{array}{c}+ \\
\text { ECHO11 }\end{array}$ & - \\
\hline Warszawa Czajka & $\begin{array}{c}+ \\
\mathrm{PV}-3\end{array}$ & $\begin{array}{c}+ \\
\text { PV-3 }\end{array}$ & + & - & $\begin{array}{c}+ \\
\mathrm{ECHO} 3\end{array}$ & - & $\begin{array}{c}+ \\
\text { ECHO11 }\end{array}$ \\
\hline Chełm & - & - & - & $\begin{array}{c}+ \\
\text { ECHO6 }\end{array}$ & $\begin{array}{c}+ \\
\mathrm{PV}-2\end{array}$ & $\begin{array}{c}+ \\
\mathrm{PV}-2\end{array}$ & - \\
\hline Total of positive results & 2 & 4 & 9 & 4 & 10 & 8 & 6 \\
\hline
\end{tabular}


2 samples were positive for enteroviruses by isolation in $\mathrm{RD}$ cells, and 4 samples were positive for poliovirus (PV) by isolation in L20B cells. All strains isolated in L20B and RD were identified as PV-3 strains by neutralization assay. Out of the 14 sample sites analysed, 12 were positive for enteroviruses by isolation in Caco- 2 cells; that was confirmed by RT-PCR reaction and isolated strains were identified by neutralization assay (Table I). Isolation was more effective when sewage samples were incubated with trypsin and trypsin was added to cell culture after inoculation. Furthermore, incubation of sewage samples on Caco-2 cell monolayer before medium addition increased positive isolation. The best results were obtained when sewage samples were incubated with trypsin and added to Caco- 2 cells in medium with trypsin (without incubation of sewage sample on cell monolayer). 34 strains of enteroviruses were isolated, $82,3 \%$ were isolated using Caco-2 cells (Table II). Strains isolated in Caco-2 were identified as different enteroviruses: poliovirus, ECHO3, ECHO6, ECHO11 and Coxsackie B (CoxB), as opposed to only polio strains isolated in $\mathrm{RD} / \mathrm{L} 20 \mathrm{~B}$.

In this study, Caco-2 cell line was used to evaluate the occurrence of enteroviruses in sewage. Samples of sewage were collected from several locations around Poland. In addition to Caco- 2 cells, samples were also evaluated by RT-PCR assay for the presence of enteroviruses, and isolated in L20B and RD cells. By means of this technique, all sample sites analysed were positive for enteroviruses and only one was positive only in RT-PCR assay. No site was negative for enteroviruses by all techniques. Caco-2 cells were more effective in enterovirus isolation than RD and L20B cells, and Caco-2 cells were also more sensitive for enteroviruses detection than RT-PCR assay. Those results clearly point to a critical issue in the interpretation of PCR findings: the presence of enteroviruses does not necessarily gen-

Table II

Isolation of enteroviruses in various cell types

\begin{tabular}{|l|c|c|}
\hline \multicolumn{1}{|c|}{ Cell type } & $\begin{array}{c}\text { No. of enterovirus } \\
\text { isolates }\end{array}$ & $\begin{array}{c}\% \text { total enterovirus } \\
\text { isolates }\end{array}$ \\
\hline L20B & 4 & 11,8 \\
\hline RD & 2 & 5,9 \\
\hline Caco-2 & 28 & 82,3 \\
\hline \multicolumn{1}{|c|}{$\begin{array}{l}\text { Incubation (-) } \\
\text { Trypsin (-) }\end{array}$} & 4 & 11,8 \\
\hline $\begin{array}{l}\text { Incubation (-) } \\
\text { Trypsin (+) }\end{array}$ & 10 & 29,4 \\
\hline $\begin{array}{l}\text { Incubation (+) } \\
\text { Trypsin (-) }\end{array}$ & 8 & 23,5 \\
\hline $\begin{array}{l}\text { Incubation (+) } \\
\text { Trypsin (+) }\end{array}$ & 6 & 17,6 \\
\hline Total & 34 & 100 \\
\hline
\end{tabular}

erate positive PCR results. Negative results are probably a consequence of the presence of compounds that inhibit RT or PCR. The presence of inhibitory factors such as metals, humic acids, and other organic matter can inhibit RT-PCR reaction (Kopecka et al., 1993).

It is interesting to note that in a study by Reigel (1985), different viruses from clinical material replicated in Caco-2 cells: enteroviruses (Coxsackie B1-B6, poliovirus types 1-3, most echoviruses and Coxsackie A viruses), adenoviruses, herpes simplex types 1 and 2, measles, respiratory syncytial, parainfluenza type 2 viruses, and to a lesser extent rubella and mumps viruses. However, Caco- 2 cells are not popular in environmental analysis. Our study demonstrates that the procedure used in inoculation process is of crucial importance. The addition of trypsin increases the percentage of positive isolation. The proteolytic enzymes have been reported to have several effects on cell cultures and virus cultivation. Enzyme treatment enhanced infectivity in most enteric viruses, for example in reoviruses (Rutjes et al., 2009). Trypsin treatment is not recommended in enterovirus isolation. That enzyme can cleavage some enterovirus capsid protein, but usually does not affect infectivity.

The diversity of enteroviruses isolated in our study in Caco- 2 cells demonstrates that sewage testing may be very useful in epidemiological study of enteroviruses circulating in the population. Sewage surveillance system has been shown to be more sensitive than reporting of clinical cases of serious illness in a community (Sinclair et al., 2008; Bosch et al., 2008). The occurrence of viruses data in raw sewage may provide an overview of the epidemiology of virus infections circulating in the community, and at the same time may reveal the occurrence of asymptomatic infections (Pinto et al., 2007; Lodder et al., 2012). The usefulness of community sewage testing to monitor the presence of polioviruses in the face of the circulation of wild type poliovirus in the community has been demonstrated in the Netherlands (Van der Avoort et al., 1995) and Finland (Poyry et al., 1988), and similar testing of sewage may be useful for the monitoring of echoviruses and Coxsackie viruses.

In conclusion, using Caco-2 cells for virus isolation in sewage seems to be very promising for environmental surveillance of enterovirus circulation and epidemiology, with all the significant effects that this may have on public health. Finally, an effective means of environmental surveillance should facilitate the monitoring of potential sources for new recombinant enteroviruses and the identification of newly discovered or previously unidentified strains.

\section{Acknowledgments}

This study was supported by Ministry of Science and Higher Education of Poland grant NN 404113839. 


\section{Literature}

Bosch A., S. Guix, D. Sano and R.M. Pinto. 2008. New tools for the study and direct surveillance of viral pathogens in water. Curr Opin. Biotechnol. 19: 295-301.

Fong T. and E.K. Lipp. 2005. Enteric viruses of humans and animals in aquatic environments: health risks, detection, and potential water quality assessment tools. Microbiol. Mol. Bio. Rev. 69: 357-371.

Hamza I.A., L. Jurzik, K. Uberla and M. Wilhelm. 2011. Methods to detect infectious human enteric viruses in environmental water samples. Int. J. Hyg. Environ. Health. 214: 424-436.

Kopecka H., S. Dubrou, J. Prevot, J. Marechal and J. M. LopezPila. 1993. Detection of naturally occurring enteroviruses in water by reverse transcription, polymerase chain reaction, and hybridization. Appl. Environ. Microbiol. 59: 1213-1219.

Lipson S.M., R. Walderman, P. Costello and K. Szabo. 1988. Sensitivity of rhabdomyosarcoma and guinea pig embryo cell cultures to field isolates of difficult-to-cultivate group A coxsackieviruses. J. Clin. Microbiol. 26: 1298-1303.

Lodder W.J., A.M. Buisman, S.A. Rutjes, J.C. Heijne, P.F. Teunis and A.M. de Roda Husman. 2012. Feasibility of quantitative environmental surveillance in poliovirus eradication strategies. Appl. Environ. Microbiol. 78: 3800-3805.

Pinto R.M., D. Alegre, A. Dominguez, W.M. El-Senousy, G. Sanchez, C. Villena, M.I. Costafreda, L. Aragones and A. Bosch. 2007. Hepatitis A virus in urban sewage from two Mediterranean countries. Epidemiol. Infect. 135: 270-273.

Pinto R.M., R. Gajardo, F.X. Abad and A. Bosch. 1995. Detection of fastidious infectious enteric viruses in water. Environ. Sci. Technol. 29: $2636-2638$

Poyry T., M. Stenvik and T. Hovi. 1988. Viruses in sewage waters during and after a poliomyelitis outbreak and subsequent nationwide oral poliovirus vaccination campaign in Finland. Appl. Environ. Microbiol. 54: 371-374.
Reigel F. 1985. Isolation of human pathogenic viruses from clinical material on CaCo2 cells. J. Virol. Methods. 12: 323-327.

Rutjes S.A., W.J. Lodder, A.D. van Leeuwen and A.M. de Roda Husman. 2009. Detection of infectious rotavirus in naturally contaminated source waters for drinking water production. J. Appl. Microbiol. 107: 97-105.

Sedmak G., D. Bina, J. Macdonald and L. Couillard. 2005. Nine-year study of the occurrence of culturable viruses in source water for two drinking water treatment plants and the influent and effluent of a Wastewater Treatment Plant in Milwaukee, Wisconsin (August 1994 through July 2003). Appl. Environ. Microbiol. 71 1042-1050

Sinclair R.G., C.Y. Choi, M.R. Riley and C.P. Gerba. 2008. Pathogen surveillance through monitoring of sewer systems. Adv. Appl. Microbiol. 65: 249-269.

Terletskaia-Ladwig E., S. Meier, R. Hahn, M. Leinmuller, F. Scheider, and M. Enders. 2008. A convenient rapid culture assay for the detection of enteroviruses in clinical samples: comparison with conventional cell culture and RT-PCR. J. Med. Microbiol. 57: 1000-1006.

Van der Avoort H., J. Reimerink, A. Ras, M. Muldres and A. van Loon. 1995. Isolation of epidemic poliovirus from sewage during the 1992-3 type 3 outbreak in The Netherlands. Epidemiol. Infect. 114: 481-491.

WHO. 2004. Polio laboratory manual. WHO/IVB/04.10. World Health Organization, Geneva, Switzerland

Witek A., M. Brzóstkowska, A. Diuwe and M. Wieczorek. 2011. Identification of infection agent in diagnostic material from patients with suspicion of enteroviral meningitis (in Polish). Przegl Epidemiol. 65:557-560.

Zurbriggen S., K. Tobler, C. Abril, S. Diedrich, M. Ackermann, M.A. Pallansch and A. Metzler. 2008. Isolation of sabin-like polioviruses from wastewater in a country using inactivated polio vaccine. Appl. Environ. Microbiol. 74: 5608-5614. 